\title{
Decolonizing Information Narratives: Entangled Apocalyptics, Algorithmic Racism and the Myths of History ${ }^{\dagger}$
}

\author{
Syed Mustafa Ali \\ School of Computing and Communications, The Open University, UK; s.m.ali@open.ac.uk \\ + Presented at the IS4SI 2017 Summit DIGITALISATION FOR A SUSTAINABLE SOCIETY, Gothenburg, \\ Sweden, 12-16 June 2017.
}

Published: 7 June 2017

\begin{abstract}
In what follows, some contemporary narratives about 'the information society' are interrogated from critical race theoretical and decolonial perspectives with a view to constructing a 'counter-narrative' purporting to demonstrate the embeddedness of coloniality-that is, the persistent operation of colonial logics - in such discourses.
\end{abstract}

Keywords: narrative; information society; colonialism; decolonial thought; critical race theory; apocalyptic worldviews; algorithmics; history; Big Data; Internet of Things; ubiquitous computing

\section{Introduction}

According to the Oxford English Dictionary, a narrative refers to "an account of a series of events, facts, etc., given in order and with the establishing of connections between them; a narration, a story, an account". Importantly, the entry goes on to state that in structuralist and post-structuralist theory, it refers to "a representation of a history, biography, process, etc., in which a sequence of events has been constructed into a story in accordance with a particular ideology [emphases added]." In what follows, I interrogate some contemporary narratives about 'the information society' from a critical race theoretical and decolonial perspective with a view to constructing a 'counter-narrative' purporting to demonstrate the embeddedness of coloniality in such discourses. My approach is informed by a concern to draw attention to three issues: (1) the presence of various strands of apocalyptic, millenialist/millenarian and utopian thinking-technological, economic, political, religious and racial-that contribute to shaping the generally tacit (and masked/obscured) background 'horizon' against which the (post-)modern information society is conceptualized; (2) the 'entanglement' of such strands in rather complex ways, thereby disrupting the possibility of straightforward linear/sequential accounting which is arguably basic to historical narrative; and (3) the need to consider the 'entanglement' of (1) and (2) in relation to the emergence of global, systemic and structural race/racism/racialization at the onset of colonial modernity during the long durée of the 16th century CE, and what I refer to as the algorithmic 're-iteration' of this systemic phenomenon in various paradigmatic incarnations up to the contemporary era ('Algorithmic Racism' (AR) is a methodological framework, metaphorically-grounded in the figure of the algorithm, for conceptualizing the relationship between processes of racial formation (or racialization) within 'Western' historical experience in relation to its (various) 'Other(s)'. AR postulates the existence of a historically-contingent, yet sedimented and 'dispositional', 'meta-process' linking racialization processes, and is motivated by a concern to assist with the disclosure of continuities masked (obscured, occluded) by transitions between different materializations-that is, 'iterations' - of race/racism in different historical epochs, and a fortiori in the transition from colonial modernity to the contemporary postmodern/postcolonial era. In this 'algorithmic' narrative, the history of 
'Western' processes of racialization involving 'paradigmatic' shifts from 'religious' to 'philosophical' to 'scientific' and latterly 'cultural' expressions of race/racism constitute re-articulations-or rather, 're-iterations' - of the difference between the human (European) and the sub-human (non-European). I maintain that AR has utility in exposing the "dark postcolonial underside" underpinning and tacitly informing developments associated with the rise of ubicomp, the IoT and Big Data/datafication, and facilitating parallel developments associated with Transhumanism and/or techno-scientific posthumanism, both rhetorical and 'material', in terms of disclosing the persistence of asymmetric race hierarchies and the 'algorithmic' (re)production of race, racism and racialization).

I begin by briefly considering some examples of information society discourse due to Luciano Floridi, Christian Fuchs, Wolfgang Hofkirchner and others that might be subjected to critique with reference to the aforementioned three issues, and then go on to look at the mobilization of the idea of 'colonialism' in contemporary discourses about Big Data/datafication, ubicomp and the IoT (Internet of Things), and how such articulations are tacitly informed by, and contribute to reproducing, coloniality - that is, the operation of colonial logics.

\section{Entangled Apocalyptics of the Information Society}

My approach to thinking through the 'entangled' logics of race, religion, technology, power etc. in relation to the apocalyptic, millenialist and utopian thinking tacitly shaping dominant information society discourse is informed by a concern to identify what I consider to be transformative events of an arguably decisive nature from a critical race theoretical and decolonial perspective. In relation to information society discourse, and drawing on Noble [1], Davis [2] and others, I argue that one such key transformation is the post-Augustinian millenialist/millenarian 'turn' (or reversal) initiated by the Cistercian monk, Joachim of Fiore (c. 1135-1202) whose 'Theory of the Three Ages', allegedly based on vision while reading the Book of Revelation, led to an interpretation of the Christian Trinity as history. I want to suggest that the historicizing of the Trinity effected by de Fiore contributed to setting in motion a train of apocalyptic developments aimed at what historian Eric Voegelin referred to as 'the immanentization of the eschaton'; furthermore, that such historicism, wedded to an increasingly positive view of the redemptive power of technology vis-a-vis recovery of the "prelapserian' condition of Adamic perfection, ensured that such historically-immanentist and 'sedimented' utopian logics of 'three-ness' continued to be re-produced-or rather, 'algorithmically' re-iterated -in various conceptual frameworks including, crucially, contemporary information society schemes such as those presented by Floridi, Fuchs and Hofkirchner.

\section{Decolonizing Information Narratives}

While recognizing the important contributions made by disciplines such as critical code studies, critical software studies and, more recently, critical algorithm studies vis-à-vis exploring the masked operation of asymmetric power in relation to algorithmic (1) mystification (positing of algorithmic agency, fetishization), (2) inscrutability (problems of access to and control over algorithmic technologies), and (3) normativity (accountability given the outcomes of algorithmic deployment), I argue that such studies tend to be framed against an assumed socio-material background of capitalism as world system that masks/occludes the constitutive colonial-and racialized-ontology of this system; further that such studies tend to focus on methods, while ignoring consideration of the body-politics and geo-politics of knowledge, thereby tacitly reproducing Eurocentric-universalism, and that there is a need to complement the critical discourse analysis of algorithms presented in such studies with a decolonial 'meta-critique' of such analyses (and their assumptions) so as to contest the universalizing tendency of such critical narratives.

Regarding Big Data/datafication and decolonial interrogation of entangled apocalypticism and the myths of history, it is interesting to note that some commentators have pointed to the 'interplay' of technology, myth and utopian/dystopian rhetoric. While broadly concurring with this assessment, I want to suggest that it is necessary to reconsider the rise of Big Data/datafication, with respect to both its rhetoric (or mythology) and its reality (or 'material' power), in terms of how this phenomenon contributes to maintaining, expanding and refining (or adapting) the racial political economy of 
global white supremacy under what is purported to be an increasingly techno-scientific postmodern/postcolonial condition. In this connection, and building on the arguments of others who refer to the construction of a 'Big Data Divide', I suggest there is a need to think about how datafication contributes to 'iteratively' re-inscribing the 'Digital Divide', itself a legacy of earlier colonial 'divides'.

In terms of mobilizing the idea of 'colonialism' within contemporary critical ('left') discourse about Big Data, arguments have been made in the literature for what is said to be a currently nontotalistic colonization of the human attention span, while others commentators have mobilized the concept of colonialism more broadly in order to think about the capitalist drivers underlying the phenomenon of datafication in terms of colonization - what is referred to as 'data colonialism'. While space precludes a comprehensive critique of these articulations, I would suggest that what is at work here is yet another race-less/de-raced-possibly even 'post-racial'-Eurocentric conception of colonialism that 'brackets' (marginalizes, erases) the 'material' links between colonialism and land, people and tangible resources, via recourse to an information-centric abstraction that allows 'colonialism' to be reductively, and economistically, framed in terms of labour. I further suggest that such a move both evinces and reproduces coloniality insofar as the discourse of 'data colonialism' coopts the signifier 'colonialism' but disconnects it from its modern/colonial signified insofar as the concrete, historical experience of colonization by the colonized is ignored, thereby obscuring continued operation of the racialized logics of coloniality.

Other examples of the invocation of colonialism in information discourses include explicit recognition within the discipline of 'postcolonial computing' of a 'colonial impulse' within ubicomp, analogically formulated with reference to 18-19th century British colonialism. From a decolonial computing perspective, such framings are useful yet problematic insofar as they occlude earlier, formative colonial projects, specifically those initiated by the Spanish and Portuguese during the 15th century which provided the historical setting for the emergence of the 'race' construct.

Finally, I want to explore what is arguably the tacit operation of a West-centric and Orientalist logic at work within the discursive framing of the digitalized and networked 'new world order' that Howard [3] suggests is emerging with the IoT (Internet of Things), and which he refers to as the 'pax technica', viz. "a political, economic, and cultural arrangement of institutions and networked devices in which government and industry are tightly bound in mutual defense pacts, design collaborations, standards setting, and data mining." (p. 297)

Acknowledgments: No funding was received to support this work.

Conflicts of Interest: The author declares no conflict of interest.

\section{References}

1. Noble, D.F. The Religion of Technology: The Divinity of Man and The Spirit of Invention; Penguin: New York, NY, USA, 1997.

2. Davis, E. Techgnosis: Myth, Magic and Mysticism in the Age of Information; Harmony Books: New York, NY, USA, 1998.

3. Howard, P.N. Pax Technica; How the Internet of Things May Set Us Free or Lock Us Up; Yale University Press: New Haven, CT, USA, 2015.

(C) 2017 by the authors. Licensee MDPI, Basel, Switzerland. This article is an open access article distributed under the terms and conditions of the Creative Commons Attribution (CC BY) license (http://creativecommons.org/licenses/by/4.0/). 